\title{
THE BIBLE IN CONTEXTUAL THEOLOGICAL WORK IN INDONESIA
}

\author{
Ebenhaizer I Nuban Timo, ${ }^{1}$ Bobby Kurnia Putrawan² \\ 1Universitas Kristen Atha Wacana, Kupang, Indonesia \\ ${ }^{2}$ Sekolah Tinggi Teologi Moriah, Tangerang, Indonesia \\ Email: bkputrawan@gmail.com²
}

Submit: 28 July 2020 Revised: 6 April 2021 Accepted: 10 June 2021

\begin{abstract}
This article describes the problem of how the Bible as the word of God is interpreted contextually for theology in Indonesia. The method used in this article is to explore contextual theological models and to have a reciprocal, constructive and dialectical dialogue between the Bible and dogma (the universal tradition) as well as the actual beliefs of the community (local traditions). The result of this research is that the meaning of God in the Bible will have a liberating and humanizing power if the meaning of God is not applied directly but in dialogue with the actual beliefs of the community where the Bible is read and preached.
\end{abstract}

Keywords: bible, word of god, contextual theology, hermeneutics, indonesia

\section{INTRODUCTION}

Recently, working on theology contextually is no longer a subject of debate among theologians, church workers (priests, elders and deacons), theology students and also most members of the congregation. It is increasingly realized that contextualization is not a seasoning added to the theological menu to be carried out in the kitchen of the faith life of individual believers and religious groups. Contextualization is the identity of every theological view whether it is formed through scientific, logical and critical reflection or expressed unconsciously without a scientific, unsystematic and illogical formulation by church members through their activities, experiences and social interactions, crocodiles, economics, daily education. ${ }^{1}$ Stephen B. Bevans, who explored the models of contextual theology, emphasized that theology, regardless of its form: whether it is intellectual understanding or reflective in nature, is and must be contextual. ${ }^{2}$

1 Judo Poerwowidagdo, Mengkomunikasikan Injil Melalui Lambang-Lambang dan Citra-citra Indonesia: Dahulu dan Sekarang. in Persetia: Berteologi Dengan Lambang-Lambang dan Citra-Citra Rakyat. (Jakarta: Persetia, 1992), 122-123.

2 Stephen B. Bevans. Teologi Dalam Perspektif Global. Sebuah Pengantar, (Maumere: Penerbit Ledalero, 2010), 229; "Models of Contextual Theology." Missiology, Vol.13, No.2 (April 1985): 185-202. https://doi.org/10.1177/009182968501300205. 
The formulation of this research is "Is there really a testimony about the Word of God (Jesus Christ) outside the Bible?" Doesn't the church itself set the Bible as the norm or canon in all spheres of church life? If other extra-biblical writings also contain the word of God, what about the determination of the Bible as canon? How is the word of God witnessed in the extra-biblical writings contrasted with the biblical testimony of God's liberating works?

In my exploration of the growing awareness of the contextual nature of each work of theology, the authors noted two points that became the foundation of this understanding. First, etymologically, theology is defined as the science or study or conversation about God. Even so, it is immediately realized that God can never be the object of study or theological analysis. ${ }^{3}$ This is what distinguishes theology as a science from other sciences such as biology or anthropology. Since God cannot and cannot be the object of theology, how should we explain the meaning of the word theology. The general opinion among church members, preachers of the word of theology students and even a large number of theologians is that the Bible is the object of theological work because it contains the word of God, there are even groups who even assert that the Bible is the Word of God. Although this view contributes greatly to the development of theological thinking and also to strengthening the faith of the Christian community, the danger that arises and has often happened is the process of substitution. The Bible is a substitute for God and His will. In a more moderate level God and His will are considered as fully and finally captured and formulated in the Bible. So if you want to understand God's will, read the Bible and do all the things that are outlined there. If there are contemporary problems that arise and no reference is found in the Bible to be used as a guide to address the problem, then the answer is already established, namely: Christians must reject today's problems because they are contrary to God's will.

This view, in my opinion, has two basic weaknesses. First, the glorious and great God, who fills all things is dwarfed to the smallest of the Bible. He who owns the heavens and the earth, who is the owner of the past, present and future is confined to the experience of Israel and the early church for a span of only about 1000 years. Allah was

\footnotetext{
${ }^{3}$ Judo Poerwowidagdo. Mengkomunikasikan Injil, 122.
} 
made a bonsai, reduced from size XXL to S. To cover this reduction effort, Allah, who had been made a bonsai plant, was configured into various beautiful and attractive shapes. Second, the biblical statement that affirms that God's plans are higher than human plans and that God's ways are not identical with human ways (Isa. 55:8-9) is instead equated with the designs, thoughts and ways of the Israelites' lives. Outside the community of biblical Israel, God's design and ways are no longer found. It can be said more deeply that God's design and way cannot be found in the experiences of Indonesians, Minahasa people, Timorese tribal communities or social ethnic groups in Maluku and Papua. Personally, authors reject this thesis, nor do authors agree with the view that everything in the Bible is God's will and therefore God's will is restricted or imprisoned in the Bible. authors have already expressed my refusal through two previous books that authors wrote with the title: Pemberita Firman Lover of Culture ${ }^{4}$ and the fingerprint of God in culture. ${ }^{5}$

Realizing the weakness of the first perception, there is a group of theologians who build the discourse that the Bible is not the object of theology. The true object of theology is faith. Theology makes the faith of a believing community the starting point for reflection. This in no way discredits the Bible. He still occupies an important role in the task of theology, not first of all because the Bible is the word of God, but the Bible contains the word of God. ${ }^{6}$ The Bible is a document that contains the struggles of faith of a group of believers at a certain time period, both during the Old Testament and New Testament times. Apart from that group there are thousands of other groups of believers who are also struggling with their faith. They do not use the Bible as a source of reflection on faith or produce the Bible as a document of reflection on faith. The source of their reflection as well as the result of their reflection is another document that is extra-biblical in nature. The extra biblical documents are in the form of sacred texts, both in written form (books) and

${ }^{4}$ Eben Nuban Timo. Pemberita Firman Pencinta Budaya. Mendengar dan Melihat Karya Allah dalam Tradisi. (Jakarta: BPK Gunung Mulia, 2006).

${ }^{5}$ Ebenhaizer I Nuban Timo. Sidik Jari Allah di dalam Budaya. (Maumere: Penerbit Ledalero, 2010).

${ }^{6}$ At this point I find a striking difference in the understanding of the faith of the two territorial or regional churches in Indonesia. The Protestant Church of Western Indonesia affirms in its understanding of faith that the Bible contains the word of God while Huria Kristen Batak Protestants in their understanding of faith emphasize that the Bible is truly the word of God. 
unwritten, namely culture and customs. The texts are believed to contain the will and thoughts of the Holy One. ${ }^{7}$

Understanding theology as a science or study of the faith of a social community gives us an open space to explore or explore the two as a whole as a space where God is present and works as well as components in the world (culture, customs, science and technology, various religious experiences such as myths, rituals, symbols, art etc.) as the means by which God's designs, thoughts, will and ways are documented. In this understanding theology does not dwarf God as a bonsai plant. God's will is also not confined to just a document. The testimony of God's saving works is broader than the book that Christians call the Bible. This first point benefits from understanding faith as an object of theological reflection.

The Bible itself supports this second point of theological position. The Bible honestly says not all the signs that Jesus did are recorded in the Bible (John 20:30). This shows that the signs Jesus made were not limited to those recorded in the Bible. Other books, which are not the Bible, should not be ignored. The books need to be read and researched because it is possible that there are also signs that Jesus did. This is also in line with revelations in other parts of the Bible. It states this: "All writings which are inspired by God are useful for teaching, for exposing error, for correcting behavior and for educating people in righteousness" (II Tim. 3:16).

If we are consistent with the choice in the second definition of the object of theology, then we must be prepared to accept the belief of the majority of non-Christian groups that the sacred documents they use as a basis for reflection of faith are also the result of inspiration from God. Don't just think about the Qur'an. Do not also limit the space of reasoning to the Bagavadgita and the Vedas. The culture and customs of tribal peoples across the face of the earth must also be made an inclusive part of the understanding of God's inspired writings. Authors even want to invite the reader to dive deeper into the discourse by building on the idea that Pancasila and the 1945 Constitution bear witness to the signs that God has wrought in Christ. Authors offer this discourse starting from the fact that the principles of divinity, humanity, nationalism, democracy, and the welfare of the

\footnotetext{
${ }^{7}$ Abraham Waigi Ng'ang'a. "Why Contextual Theology Matters for the Church." InSights Journal for Global Theological Education, Vol.3, No.1 (2017): 25-32.
} 
people contained in Pancasila point directly to the heart of the preaching of God's government which was witnessed by Jesus. It is not an expression of social piety or mere subjective feelings, but a statement of faith, when in the preamble of the 1945 Constitution the founders of the Republic of Indonesia affirmed that Indonesia's independence was thanks to the grace of God Almighty.

The name of Jesus may not be explicitly mentioned in those books, but the signs that Jesus did, the values of life that Jesus exemplified and taught were no less elaborated and made the golden role in these writings. It should be admitted that in these extra-biblical writings there are many paragraphs and sentences, expressions and symbols that have demonic and diabolical content. It can't be denied. But aren't these diabolical and demonic nuances also detected in the Bible? If we say that the diabolical-demonist nuances in the Bible are against God's will, why don't we say the same about the diabolical-demonist elements in the extra-biblical writings?

Theology by becoming faith as an object of reflection has a second advantage, namely that the purpose of theological reflection is no longer understood simply as a substitute for culture and religious experience but rather as reparation. Believing in God in Christ does not necessarily mean abandoning the religious ideas, culture, and customs that we have as Indonesians, Papuans, Moluccans, Timorese, Minahasa, Javanese, Dayak and Batak. This is what authors mean by pattern substitution, which should not be the case. Believing in the Triune God means making reparation for the holes or damages in our religious beliefs, culture and customs caused by these diabolical-demonist elements. ${ }^{8}$ Just as the life of the Israelite faith community in the OT and the early Christian community in the NT which was full of holes or damage caused by diabolical-demonist elements was repaired by an understanding of God's will revealed in Christ, so the diabolical-demonist holes found in the texts the sacred text of the non-Christian faith community also needs to undergo the reparation process. The agreement at the inaugural synod in Jerusalem (Acts 15) that Greek believers in Jesus should not be forced to fulfill all the obligations of Jewish culture must be understood from this perspective, namely that the Gospel is not aimed at cultural substitution, but reparation. With the decision of this first synod, said David W.

\footnotetext{
${ }^{8}$ Abraham Waigi Ng'ang'a. "Why Contextual Theology Matters for the Church", 25-32.
} 
Shenk, "the Church becomes a community that enjoys amazing diversity, but at its heart there is oneness in a shared commitment to Jesus Christ as Lord." 9

Authors became more and more sure, the long introduction that authors made above had provoked anxiety in the hearts of readers which must have been formulated in sentences similar to the one authors formulated: "Is there really a testimony about the Word of God (Jesus Christ) outside the Bible?" Doesn't the church itself set the Bible as the norm or canon in all spheres of church life? If other extra-biblical writings also contain the word of God, what about the determination of the Bible as canon? How is the word of God witnessed in the extra-biblical writings contrasted with the biblical testimony of God's liberating works?

This is contextual theology. It does not intend to become a universal theology, applicable in all places and times, as the attributes that we have given to intellectual theological works from Europe are actually contextual in nature for European society. Contextual theology aims to provide a social, anthropological, historical, political, cultural etc. flavor for the reflection of human faith in various contexts.

\section{METHODS}

The research method used in this article is descriptive qualitative, which uses a hermeneutic approach to fuzi horizan. This approach seeks to dialogue with existing models in contextual theology, meaning that a fusion horizon hermeneutic perspective like this presupposes that biblical texts and formulations of dogmas and actual beliefs of society in culture need to undergo a double process, namely reproduction-traditional and productive- contextual.

Authors will start this article by offering a new understanding of the meaning of the church's establishment of the Bible as canon. In the same section authors will describe the relationship between the word of God witnessed in the Bible and the word of God in extrabiblical documents. Various methods of reading the Bible will also be the subject of this article. In closing I will submit my proposal on how the Bible should be read in an effort to

9 David W. Shenk. Ilah-Ilah Global. Menggali Peran Agama-Agama dalam Masyarakat Modern. (Jakarta: BPK Gunung Mulia, 2006), 306. 
contextualize specifically for Christians in Indonesia. authors will strengthen this proposal by showing two examples of its application in the contemporary life of the congregation.

\section{RESULT AND DISCUSSION}

\section{Canon for the Life of the Church: The Bible or the Word of God}

It has become a common tradition or custom among church members and theologians to treat the Bible as the canon or standard for all practices of church and Christian life. Authors do not reject this tradition. The discourse that authors propose here is to invite us to get used to the truth and not justify the habit. The Bible is the only rule of truth. This has been accepted as a universal truth among Christians. In the life of the church in Indonesia by some Christian communities this principle is elaborated in the recognition that the Bible is truly the word of God. ${ }^{10}$ While there are other Christian communities who take a moderate stance. For them the Bible is not the Word of God but contains the word of God. The success or failure of the contextualization effort depends on the choice we make with this option: Is the Bible the Word of God or is the Bible the Word of God? This choice raises another question: which one deserves to be the canon (the rule) for the life of the church and Christians, the Bible or the Word of God?

Personally authors would argue that holding to the principle that the Bible is God's word makes contextualization difficult. Even if the Bible was truly the word of God, the pastor would no longer need to preach at every Sunday service. It is enough that the Bible is read aloud and then the priest confirms that what was read earlier is done because it is the word of God. A more suitable choice for the task of contextualization is that the Bible contains the word of God. Starting from this choice, the rule of truth for the life of the church and Christians is not the Bible but the word of God. This attitude departs from three points of reasoning. First, making the Bible the rule of truth in the sense that the Bible is the word of God only results in the emptying of all religious beliefs, cultural values and the provisions of the customs of the Bible-reading community to be replaced with religious understanding, cultural values and provisions of the customs of the Bible-writing community. . There is what authors called above the substitution pattern. Because the Bible

10 Kantor Pusat HKBP. Panindangion Haporseaon. Pengakuan Iman HKBP. (Pematang Siantar: Unit Usaha Percetakan HKBP, 2009). 126. 
is the word of God, the things that are written there, both the mindset, culture, customs, religious practices, social and even the government system of the Israelites are considered as absolute, definitive and universal divine decrees. This is something that has happened in many Indonesian Christian circles. The culture and way of life of the preachers in the Bible was transferred to the Christian community in Indonesia. Second, in the Bible itself it is emphasized that the measuring instrument for the Christian life with all the intricacies of its affairs is the Word of God, namely Jesus Christ (1 Cor. 12:3, Phil. 2:5-7, I John 4:2-3). ). There is absolutely no mention of the Bible as a measuring tool. Of course the Word of God (Jesus Christ) that is used as a measuring tool is what is witnessed in the Bible, but that does not mean that the Bible is $100 \%$ identical with the word of God.

In the background section, authors have mentioned a little about the appreciation of the faith of the non-Christian believing community about the inspiration of the truth or the word of God in sacred non-biblical documents. The Bible itself also acknowledges the existence of the inspired truth and word of God outside the biblical books. This implies that we should not confine the word of God in words and sentences in the Bible. God's Word is bigger than the Bible. According to II Timothy 3:16, the extra-biblical words which are inspired by God have the same function as the words in the Bible, namely to lead people to build lives according to the teachings and example of Christ. The thing that distinguishes God's word in the Bible and outside the Bible is in the functional scope of the two. The Word of God (Jesus Christ) which is witnessed in the Bible is the rule of truth that is global and transcends the times, primary while the anonymous word of God applies locally and is periodic, secondary. ${ }^{11}$ Jesus Christ is the primary word. The Bible's testimony of Jesus Christ is the secondary word of God. It is the fruit of faith in the OT and NT community of God's people, while the word of God and the extra-biblical inspired writings and signs of God are the anonymous word of God. authors chose the word anonymous because the name of Jesus is not explicitly mentioned. Even though they do not explicitly mention the name of Jesus, these writings are also the word of God because they were inspired by God. The holy books of religions as well as cultural instruments and community customs are included in the anonymous word of God. Pancasila is also the word of God anonymously 2017), 109.

${ }^{11}$ Ebenhaizer I. Nuban Timo. Meng-hari-ini-kan Injil di Bumi Pancasila. (Jakarta: BPK Gunung Mulia, 
considering its values are commensurate with the teachings of Jesus. These writings should also be seen as the rule of truth.

In an effort to contextualize theology in Indonesia, or the name authors prefer, which is to give Indonesian genetics to theology, christology, pneumatology, ecclesiology, etc., it is not enough for the church and Indonesian Christians to just listen to the Word of God in the Bible. The primary and secondary words of God are sufficient for salvation (John 20:30-31). But so that salvation has an Indonesian taste, the non-biblical word of God, namely in the cultural, historical and political repertoires as well as the supernatural appreciation of the Indonesian people needs to be taken into account. The Word of God in Christ witnessed by the Bible guarantees definitive salvation for all creation, while the anonymous word of God in the texts of society gives Indonesian genetics to its understanding and application. In my opinion, this is the soul of the Dual Struggle which is the recommendation of the Communion of Churches in Indonesia in carrying out the task of contextualizing theology. ${ }^{12}$

In the task of contextualizing theology, the Church reads the Bible to understand God's work of salvation once and for all. But the Church also needs to read and understand extra-biblical documents to give the Indonesian flavor of salvation. The affirmation of God's word is the rule of truth intends to underline two things: God's word in the Bible (Jesus Christ and the experiences of the OT and NT people) becomes the mondial and definitive norm while the extra-biblical word of God becomes the local and periodic norm. Understanding the word of God in the Bible and non-biblical sacra scriptura is useful for the church. ${ }^{13}$ Of course the role of the Holy Spirit in the process cannot be ignored.14

In conclusion, the rule of truth for the Christian life is not the Bible. The rule of truth is the word of God (Jesus Christ). Al-Quran, Bhagavadgita, Vedas, or other sacra scriptura, even the religious beliefs of people in culture are also writings inspired by Allah. These writings are the rule of truth in a local and periodic sense because the word of God in these writings is anonymous because it does not explicitly point to Jesus.

12 Nuban Timo. Meng-hari-ini-kan Injil. 110.

13 A.A. Van Ruler. "Schriftgezag en kerk ." in Rondom het Woord. Theologische Etherleergang van de NCRV, No.3, (Juli. 1968), 348; Abraham Waigi Ng'ang'a. "Why Contextual Theology Matters for the Church": 25-32.

14 Karl Barth. Church Dogmatics, The Doctrine of the Word of God 1.2. (New York: T\&T Clark, 2010), 473. 


\section{Various Methods of Bible Reading}

Not a few studies of the Bible reveal that the writings in the Bible that we mention the word of God are nothing more than the result of the faith struggle of believers in the OT and NT in answering God's call in their concrete situations. ${ }^{15}$ The truth that is formulated there is contextual, that is, it is tied to the cultural and historical experiences of the ancient Middle Eastern people. We read the testimonies not to apply all that is written there but to find Christ. This should be a footnote when you want to read the Bible. Because the socalled truth in the Bible is Christ (His example and teaching), not the culture, customs and religious views of the OT and NT people.

Just as Jesus Christ came into the world in the form of a little baby in Bethlehem wrapped in swaddling clothes and lying in a manger, so the word of God was spoken to man in human words. Thus the completion of the thinking of Marthen Luther and Karl Barth. Because this is the case, the Bible must be read carefully so that what humans find in the Bible is not a manger and swaddling clothes, but Jesus Christ even though he is still in the form of a baby. In this regard, throughout the history of Christian theology there have been at least 4 methods or paths taken to read the Bible. Authors will describe this in some detail in this section.

Groenen called the allegorical method the most ancient and common method of reading the Bible. The allegorical method is used to get a new meaning from a text, a meaning that has been spiritualized. Generally a text always contains three meanings: literal, moral and spiritual. The allegorical model pays less attention to facts and literal meanings. Allegory is more interested in the moral and spiritual similarities between a text and an existing doctrine or dogma so that it can be used as a basis to justify existing teachings. ${ }^{16}$ For example, the fig tree that Zakeos climbed was called the tree of pride, the tree of envy, and so on. Because Jesus asked Zakeos to come down from that tree to meet Jesus, believers today must also come down from all the trees that exalt their lives if they

15 David Robert Ord \& Robert B. Coote. Apakah Alkitab Benar? Memahami Kebenaran Alkitab Pada Masa Kini. (Jakarta BPK Gunung Mulia, 2016). Mulia), 32.

${ }^{16}$ I. Cairns. (1985). Perjanjian Lama dan Indonesia Yang Sedang Membangun. (Jakarta: BPK Gunung 
want to meet Jesus. Allegorical interpretation was most developed in one of the centers of ancient Christianity, namely in the city of Alexandria (Egypt). ${ }^{17}$

This allegorical model by E.G. Singgih is referred to as a pre or non-critical interpretation. In this model the meaning of the text is determined by a particular teaching system or theology. For example, the doctrine of the Triune God which the church formulated in the dogma of the Trinity is already in the head and heart of every Christian. When Genesis 1:2 is read and explained, the Trinity Dogma becomes the discussion format. Clearly, Genesis 1:2 confirms the truth of the Christian teaching about the trinity of God. ${ }^{18}$

Of course there are benefits of pre-critical reading there are benefits. It motivates listeners to strengthen moral commitment and firm faith. The weakness of this method is the neglect of the facts and the meaning of the text itself. Text is not interpreted autonomously but as dependent on something outside the text. That way the text (the word of God) is used as the basis for justifying views and opinions that already exist outside the text. The work of exegesis turns into eisegese. God's will is subject to human thought rather than correcting and straightening human will. The text no longer performs the function of teaching, criticizing errors, stepping on to correct behavior and guiding to the truth (II Tim. $3: 16)$. Obviously, in the first way of reading the Bible the search for meaning from the text is oriented to religious beliefs or dogmas that are outside the text.

The second way of reading the Bible is the application of modern hermeneutics, namely the application of the historical critical method to the interpretation of the Bible. ${ }^{19}$ This model already has its origins in Antioch in ancient Christianity. ${ }^{20}$ The Antioch school pays attention to the literal meaning of the biblical text. This method is then called historical critical interpretation by modern scholars. In my opinion, the meaning of the text is oriented in the text, either to the author of the text or to the general understanding of the first readers or the purpose of writing the text. Attention to context becomes an important point after the interpreter reads the text. What is meant by context are: first, the verses that precede and follow. The meaning of the text is determined by the relationship of the text to the texts before and after it. So the meaning of the text is sought in the text itself, not

${ }^{17}$ C. Groenen. Hermeneuse Alkitab..., 13.

${ }^{18}$ E.G. Singgih. Apakah Yang Disebut “Tafsir Feminis?” Penuntun, Vol.4, No.16 (2000): 426.

${ }^{19}$ C. Groenen. Hermeneuse Alkitab... 14.

${ }^{20}$ C. Groenen. Hermeneuse Alkitab... 13. 
searched outside the text as in the allegorical method. Second, what is also called context is sitz im leben or the historical, social, political and religious situation of the text.

The historical-critical way of reading starts from the interpreter's attempt to find the meaning of the text objectively, centered on the text and its context. How far his findings are useful for the Christian congregation today is not the main concern of the interpreter. The main goal is to get the meaning of the text. If that goal has been obtained, the next step is to find a relationship between the meaning in the text and the faith life of today's church members. The second step is done typologically. ${ }^{21}$

The strength of this method is that the literal meaning of the text is upheld. Its weakness is similar to the first method, namely the denial of the interpreter and his need. In fact, if the interpreter is honest, it becomes an important component that determines the meaning of a text. Doesn't everyone experience for themselves that something that was considered true and valuable in the past or in a different context, is not automatically true and valuable in the present or in a new context. These weaknesses open up space for the discovery of alternative methods that have a dual capacity, namely being able to cross the literal meaning of the text to the present without destroying the original meaning but the meaning that is crossed is not forced in the present.

An alternative to it is offered by Rudolf Bultmann and colleagues. The model they design is called existential interpretation. The historical-critical model is still appreciated, namely to find the objective meaning of the text in its context. What is new from the existential interpretation method is that the self and the interpreter's understanding also receive attention. After the contents of the announcement of the events that are confirmed in the text are found, the report is immediately applied to the interpreter. This application is necessary to free the content of the proclamation in the text from mythological concepts which are considered to have frozen the proclamation. In other words, the application aims to re-actualize the messages in the text. This is what Rudolf Bultmann calls demythology. Bultmann proposed this program with the intention of confronting contemporary humans with messages (kerugma) so that humans make decisions to reject or accept the message. ${ }^{22}$

${ }^{21}$ Nuban Timo. Meng-hari-ini-kan Injil, 125.

${ }^{22}$ Nuban Timo. Meng-hari-ini-kan Injil, 125. 
Bultmann's discovery method succeeded in reviving the message of the Bible that was packaged in mythological language. Modern humans are confronted with the contents of the Bible's proclamation that has already been cleansed of the myths that wrap the message. Bultmann describes this position very beautifully in a book entitled: Geloof Zonder Mythe. There Bultman emphasized the following. "If the results of historical investigations show that the historical description or reference in the Bible is wrong, the Bible can still be trusted because what the Bible focuses on is not the meaning of events in the past, but its usefulness for human life today."23 authors quote this assertion to show the weakness of the existential interpretation reading model offered by Bultmann. This method does what authors call emptying the Bible. ${ }^{24}$ God's saving work in historical events witnessed by the Bible is considered less important, it can even be removed. Whether or not events are true doesn't matter to us now. Our problem is whether the message of the Bible is understood by modern man, that is, today's man gets something that answers his existential needs.

In response to the shortcomings of the three methods above, a new method was initiated by E.G. Singgih calls this model a narrative-critical interpretation. This method has similarities with historical-critical, namely attention to the text and its literal meaning. What distinguishes it from the historical-critical model is the way in which text messages are obtained, namely through examining the role of the narrator or storyteller, entering the world of the story. ${ }^{25}$ The interpreter tells something (event or fact) because there is something he wants to convey to today's believers. Nico Ter Linden's book which was translated by BPK Gunung Mulia with the title: "The Story Continues..." is the application of the narrative-critical interpretation model. ${ }^{26}$

Groenen's offer of Bible reading methods is somewhat close to narrative-critical interpretation. That method is biblical hermeneutics. ${ }^{27}$ Groenen himself prefers the name hermeneutic circle. The problem that arises from the previous methods is the neglect of literal meaning, or the denial of the importance of historical facts or events in the service of

\footnotetext{
23 Rudolf Bultmann. Geloof zonder mithe.

${ }^{24}$ Nuban Timo. Meng-hari-ini-kan Injil, 126.

25 E.G. Singgih. Apakah Yang Disebut "Tafsir Feminis?" 433-4.

${ }^{26}$ Nico Ter Linden. Cerita Itu Berlanjut... (Jakarta: BPK Gunung Mulia).

27 C. Groenen. Hermeneuse Alkitab... 24.
} 
the interpreter's existence. The other method is more interested in the literal meaning and ignores concern for the here and now people. According to Groenen, these methods allow the Bible's message to be completely absorbed. If the meaning of the text is successfully understood, the meaning is then determined as the norm. This means that it is no longer allowed to look for new meanings for new situations and conditions faced by the interpreter. Or if there is a new meaning then the price of that meaning is underestimated. ${ }^{28}$ Call it, for example, negative texts about homosexuality. The meaning of the texts is considered final. Attempts to find new manka from these texts are forbidden. There should be no further discussion of the new meanings.

The hermeneutic circle model makes understanding (not just knowing and knowing) the core of the work of interpretation. Understanding the meaning: understanding the meaning of something. The main requirement for that purpose is the existence of a relationship between the object and the subject in the process. ${ }^{29}$ The main problem in biblical hermeneutics is: "How can humans in a responsible (scientific) way come to a true understanding of the Bible? What are the prerequisites and how does the process proceed?" 30

Groenen put forward two preconditions. First, understand the pre-understanding of the Bible. Pre-understanding has two sides, namely pre-understanding of the subject of Bible readers and pre-understanding of the subject of preachers in the Bible. what is meant by the subject of Bible readers is today's people, anywhere and anytime. Everyone who studies the Bible certainly has a certain position and attitude towards the text being investigated and the problem to be solved. The reader certainly departs from the belief that the biblical text has a message that can help him live in the here and now. This is called the existential element of the interpreter. According to Groenen, pre-understanding is different from preconceived notions or preconceived notions. Presence is open to correction, correction, modification and correction after the process of Bible study, while prejudice

\footnotetext{
${ }^{28}$ C. Groenen. Hermeneuse Alkitab..., 59-60.

${ }^{29}$ C. Groenen. Hermeneuse Alkitab..., 25.

${ }^{30}$ Nuban Timo. Meng-hari-ini-kan Injil..., 127.
} 
does not open the door. Pre-understanding recognizes the Bible as an authoritative and critical institution, while prejudice ignores it. ${ }^{31}$

Regarding the events in the Bible Groenen asserts that the preachers see these events not as information for the study of history, biology, mathematics, etc. These materials are the proclamation of their faith. The purpose of the reporting is to inspire confidence in today's readership. Reading the Bible means uniting yourself with the preachers of the Bible, joining in the search and discovery of the testimony contained in historical events. The discovery of that content needs to be brought into the present to be used as a basis for life. This is the pre-understanding of biblical proclaiming texts. ${ }^{32}$

The second point is the attention to sitz-im-leben in the hermeneutic process, namely the social environment, political situation, economy, historical and cultural framework in which hermeneutics takes place. There are also two aspects to this point: the sitz-im-leben of the Bible readers and the sitz-im-leben of the preachers of the Bible. The events in the Bible are actually a reflection of faith in God from the preachers in responding to the specific situations and problems they face. Hermeneutics needs to pay attention to this original context. But hermeneutics also needs to pay attention to readers who search the Bible. Making a direct application of the Bible's testimony to today's life is inappropriate. In fact, it distorts the Bible. Hermeneutics examines biblical texts not to make a direct application of the preaching tradition of the past to the present. Hermeneutics is tasked with guiding Bible readers to understand and assess the historical nature of the biblical tradition, so as to be able to distinguish the parts that are the core of biblical preaching from those that are only on the margins of the biblical faith tradition. ${ }^{33}$ This understanding is a call for them from the horizon of their understanding to respond to the proclamation: strengthening faith and preventing fundamentalist views. ${ }^{34}$ In this process the biblical tradition is actualized in a new situation. What Gronen introduces has very big parallels with the fusion of two horizons which became Gadamer's notion of hermeneutic task. ${ }^{35}$

\footnotetext{
${ }^{31}$ C. Groenen. Hermeneuse Alkitab..., 53.

32 C. Groenen. Hermeneuse Alkitab..., 30-1.

33 C. Groenen. Hermeneuse Alkitab..., 57.

${ }^{34} \mathrm{C}$. Groenen. Hermeneuse Alkitab..., 35.
}

35 Welfrid Fini Ruku. Fenomena Kutuk/Berkat di Rumah Naomi. Hermeneutik Etnofenomenologi Atoin Meto di Timor Atas Kitab Rut 1:1-6. Disertasi Doktor. (Yogyakarta: Program Pasca-Sarjana S3 Ilmu Teologi Universitas Kristen Duta Wacana Yogyakarta, 2017), 29-31. 
Uniting the two different horizons was not an easy job. It demands energy and perseverance, even teamwork: one person checks the Bible evangelist's preconceptions and sitz-im-leben; another colleague analyzes the pre-understanding and sitz-im-leben of Bible readers. Pastors and preachers use the results of the two groups for the final step, namely the hermeneutic circle.

This method emphasizes that we cannot directly apply the material in the Bible to the contemporary life of Bible readers. Even Jesus never did a direct application of the faith texts in the scriptures of His people. Generations before Jesus crystallized their faith in God in the rule: "An eye for an eye, a tooth for a tooth." Jesus did not necessarily apply the rule to His present situation. He re-actualized the tradition. "You have heard the saying: An eye for an eye and a tooth for a tooth. But authors say to you, do not resist the one who does evil to you, but whoever slaps you on the right cheek, turn to him your left also" (Matt. 5:38-39). This Jesus and John made the Gospel today in order to instill the message of Easter and Pentecost in the hearts of His listeners. ${ }^{36}$ This is an example for today's believers in reading and using the Bible as a norm in the task of contextualizing theology.

\section{Reading the Bible in Indonesia}

The task of contextualization is actually an effort to make meaning rather than receiving meaning. ${ }^{37}$ The methods of reading the Bible that authors show above lead to this goal. The preachers in the Bible have already constructed the meaning of their faith in God in the social, cultural, economic, political and religious dynamics they face. The meaning of Allah in the Bible is not something that is given, sent down from heaven like the Islamic view of the Qur'an. ${ }^{38}$ The Bible is also not the minutes of the meeting between God and man as is commonly understood by Christian Pentecostal, Evangelical and Charismatic groups. The Bible is a crystallization of the human experience of association with God. ${ }^{39}$ The Bible is a man-made proclamation. ${ }^{40}$ It is boek-van-ontmoeting. ${ }^{41}$ The Bible is human writings

${ }^{36}$ Nuban Timo. Meng-hari-ini-kan Injil, 129.

37 Ebenhaizer I Nuban Timo. Polifonik bukan Monofonik. (Salatiga: Satya Wacana University Press, 2015), 181.

38 J. Verkuyl. Met Moslims in Gesprek Over het Evangelie. (Kampen: J.H. Kok, 1994), 35.

39 J.T. Bakker. "Het gezag van het schrift." Dalam Rondom het Woord. Theologische Etherleergang van de NCRV. No. 3 - Juli. 1968. 380.

40 Nuban Timo. Nuban Timo. Meng-hari-ini-kan Injil, 130. 
produced by the experience of encountering God. Because the story about the experience in oral form to others is not enough because it will experience continuous deviation, the bookkeeping of the stories becomes a necessity. One or more people appear as editors who put the writings together. The existence of various literary forms of the writings in the Bible is a direct consequence of the work of the editor whose main task is to put these writings together. It is clear that the Bible contains God-meaning proclamations that are constructed by believers to answer their contemporary problems at that time. The Bible is a theological contextualization of the preaching community in the Bible.

The effort to formulate the meaning of God has not been completed even though the Bible has been completed. People who live after Bible bookkeeping are in social, cultural, economic, political and religious conditions that need meaning. It is clear that the meaning of God that has been recorded in the Bible cannot be directly used because the questions faced by believers today are different from the questions faced by preachers in the past. The meaning of God as a result of the construction of people in the Bible is indeed useful, not to be simply copied but to be used as a guide in constructing meanings that are relevant to new situations. In the process in that direction, the process of deconstruction reconstruction becomes unavoidable. It is clear that Bible readers do meaning-making work starting from the meaning of God that has been constructed by Bible preachers while considering the elements of God's word that are stored in the experience of believers in Bible readers. ${ }^{42}$ Karl Barth said: "We are not called to revive the faith traditions of the prophets and apostles. We are asked to live a new life of faith according to the example of the prophets and apostles. The faith tradition of the prophets and apostles is necessary because it shows that faith is a living thing. Jaroslav the Pelicans asserted that tradition is the living faith of the dead. ${ }^{43}$ But it is not faith traditions that we revive. Doing so is the same as applying dead faith to the living. ${ }^{44}$ What we have to do is make the faith tradition a

41 Henk van Andel (Ed. 1990). De bijbel opnieuw... gelezen, uitgelegd, overwogen. 's-Gravenhage: Meinema. 53.

42 Nuban Timo. Nuban Timo. Meng-hari-ini-kan Injil. 130.

43 Kelly M. Kapic. Pedoman Ringkas Berteologi, Mengapa dan Bagaimana Study Teologi. Diterjemahkan oleh Paul S. Hidayat. (Jakarta: Waskita Publishing. 2014). 92.

44 Jack Deere in his book Surprised by the Power of the Spirit, Grand Rapids, Michigan: Zondervan Publishing, 2020 (especially in Chapter 4) shows clearly that the majority of Christians hold fast to one truth of faith (about the divinity of Jesus, Salvation, gifts of miracles) not primarily because they examine the Bible carefully and deeply. They believed in these truths because they were taught to them by people they 
wealth to reconstruct meanings that are relevant to our present situation.

In an article, Pastor Philip Hughes emphasized that the task of meaning-making in theology should pay attention to actual beliefs, namely the beliefs of a society that are used as a guide in regulating their behavior and actions both communally and for each individual member. ${ }^{45}$ These actual beliefs are found in art, poetry, literature, dance, music that people create or use. Their beliefs related to the universe and how they live are often found in folklore, in proverbs and also in the products of customary laws, as well as socio-political constitutions. 46

The community's actual beliefs are the formation of identities and views about life and the world of the community in question. Meaning-making which is the character par excellence of the theological task cannot pass the actual beliefs of the people from across the street. The Bible and actual beliefs should be dialogued with each other in carrying out the contextualization of theology. Thus contextual theology is no longer a single-text effort, but multi-texts. ${ }^{47}$ This multi-text struggle is described by Joas Adiprasetya as an attempt by a theologian in his relationship with the entire faith community to treat the diversity of texts owned by creative and imaginative processing of intertextual relations. Multi-text refers to theological texts, namely the Bible, and non-theological texts that are sociological texts from religion and society. ${ }^{48}$ In Indonesia, the texts are divided into two groups. First, the sacred texts of pre-Indonesian tribal and ethnic communities, namely before 1945. Second, Pancasila and the 1945 Constitution.

respected and admired. Holding the truth in this way, according to Jack Deere, on the one hand can be misleading, but what often happens is that the truth is understood in a narrow and static way. So that what we receive from people we respect lead us to an authentic knowledge and belief, it is very beneficial if we ourselves study and study the Bible consciously. With the same goal, HM Kuiter, as we quoted above, said: "The Bible has value as the Word of God because what is written in it is read and understood by taking into account our present experience, and not vice versa, a theory about the uniqueness of the Bible is used to give value. to what is written in it."

45 Philip Hughes. "The Use of Actual Beliefs in Contextualizing Theology." in East Asia Journal of Theology. Vol.2 No.2 (October 1984): 251.

46 Nuban Timo. Meng-hari-ini-kan Injil, 131.

47 Ebenhaier I Nuban Timo. "Sosiologi Agama dalam Perspektif Teologi Dogmatika." in Izak Lattu, Rama Tulus Pilakoanmu, Ebenhaizer I Nuban Timo, Steven Gaspersz (ed). Sosiologi Agama Pilihan Berteologi di Indonesia. Salatiga: Fakultas Teologi Universitas Kristen, Satya Wacana Press, 2016), 42.

${ }^{48}$ Joas Adiprasetya. "Teologi Konstruktif dan Wajah Sosiologi Agama." in Izak Lattu, Rama Tulus Pilakoanmu, Ebenhaizer I Nuban Timo, Steven Gaspersz (ed). Sosiologi Agama Pilihan Berteologi di Indonesia. (Salatiga: Fakultas Teologi Universitas Kristen Satya Wacana Press, 2016). 257-8. 
In the task of contextual theology in Indonesia, multi-text dialogue is a must in an effort to make meaning-making with an Indonesian flavor. The meaning of God produced by Bible preachers will only be applicable when it is read and understood in relation to theological and non-theological texts that guide the life of the Indonesian people and nation. The texts referred to are texts of pre-1945 tribes and ethnic groups and the joint text of the Indonesian nation, namely Pancasila and the 1945 Constitution. Theological work in Indonesia so far, namely the Bible as the only sacred text and Indonesia with two sides. as the context needs to be reformed. Indonesia itself needs to be seen as a text, namely its cultural, historical, political and ideological texts. ${ }^{49}$

The reasons for the importance of multi-text dialogue are as follows. Theology is not just a science. It is more a reflection of one's faith or the faith of the Church in the dynamics of the life of a society. Faith grows in life situations with social, cultural and political backgrounds. Theology that does not care about God's real work and human answers to that real work in a concrete context is only a theory. Calvinism, Lutheranism, Barthianism and even the meaning of God in the Bible are also theories. These are more precisely the different forms of response of believers in certain social and cultural circles to God's real work in their time and society. These responses cannot be seen as universally applicable formulas to explain knowledge about people's lives in different times and places. We need Calvinism etc. as a theoretical framework in an effort to formulate our own response from within the concrete experience of faith in Indonesia. ${ }^{50}$ Authors mention here two examples.

The gospel is experienced as a concrete liberating power, in fact through cultural mechanisms or the actual beliefs of the community where the gospel is understood. The God we believe in in Jesus Christ expresses approval of worship to Him which is carried out by taking into account the cultural processes and manners of life outlined in the customs of the cultural ancestors of each society. It shows the fact that living in trust and hope only in God who manifests Himself in Jesus Christ is not an anti-cultural life. The typology of Christ against culture summarized by $\mathrm{H}$. Richard Niebuhr in his book Christ and Culture is indeed one model of developing a life in faith in Christ, but this model tends to produce believers who are very faithful to the Hellenistic-style gospel while losing their local cultural identity.

\footnotetext{
${ }^{49}$ Nuban Timo. Meng-hari-ini-kan Injil. 132.
}

${ }^{50}$ Nuban Timo. Meng-hari-ini-kan Injil. 133. 
Such belief not only makes the gospel a foreign message, it strips the gospel of its liberating power.

Ruku proposes a hermeneutic ethno-phenomenological method as a way of reading the Bible which is practiced by most church members in Timor. The successive deaths of three adult males in Naomi's house are no ordinary death alphabet. Timorese Christians saw that something was wrong, condemned in the tragedy. Naomi's decision to return to Bethlehem, marrying Ruth to Boaz, which resulted in Obed's birth is also deeply rooted in the actual beliefs of the Timorese Christian community as a healing mechanism for dealing with curses. Timorese Christians see that God is working to reveal the liberating power that is in the Bible through the channels available in the culture and customary - social mechanisms of the people. This method is interesting because the gospel comes alive in the experience and has real liberating power. ${ }^{51}$

In the case of the sacred texts of post-1945 Indonesia, dialogue between the Gospels and Pancasila is a hermeneutic process of fusion of two horizons that is necessary in the context of finding the meaning of peaceful and non-discriminatory coexistence in a country like Indonesia where pluralism is understood as a given and not as a choice. It is no secret that the religions that currently exist in Indonesia come from other countries. They are imported religions. They came to Indonesia with sacred texts that were believed to be revelations from God, God's mercy and grace for the nation who received the revelation. In their place of birth, these religions are the children of the masses and demand to be made the religion of the children of the masses. ${ }^{52}$

The founders of the country named Indonesia openly admitted that Indonesia with Pancasila and the 1945 Constitution was not just a socio-political phenomenon. It is also a theological phenomenon. Long before these religions came from the sea, Pancasila was already in the womb of Indonesia. Indonesia with Pancasila as given is explicitly explained in the opening of the third paragraph of the 1945 Constitution which states that Indonesia's independence is thanks to God's grace. God wants Indonesia to exist as a nation with

51 Welfrid Fini Ruku. Fenomena Kutuk/Berkat di Rumah Naomi. Hermeneutik Etnofenomenologi Atoin Meto di Timor Atas Kitab Rut 1:1-6. Disertasi Doktor. (Yogyakarta: Program Pasca-Sarjana S3 Ilmu Teologi Universitas Kristen Duta Wacana Yogyakarta, 2017).

${ }^{52}$ John A. Titaley. Religiositas di Aline Tiga. Pluralisme, Nasionalisme dan Transformasi Agama-Agama. (Salatiga: Satya Wacana University Press, 2013), 53. 
Pancasila and the 1945 Constitution. If in their country of origin, the imported religions competed with each other to become children of the masses, in Indonesia with Pancasila and the 1945 Constitution, each religion is required to abandon the claims of the sons of mas and learn to build a culture of equality. Pancasila calls on these religions to see people of other religions as fellow children of the nation as part of the same religiosity and therefore they are no longer competing but working together to build a just, prosperous, prosperous and sustainable Indonesia. This call, said John A. Titaley, is not a denial of the missionary character (da'wah) of these religions. Rather it is a kairos, a new perspective that gives hope to these religions showing their missionary task beyond conventional boundaries and their own religious understanding. ${ }^{53}$ Borrowing the statement of A.A. Yewangoe's calling in Indonesian society is to establish the kingship of God, not the kingdom of God. The point is not to build a Christian kingdom territorially but to show God's government in all aspects. 54

The examples above may be enough to inspire us and make us wiser to see that the meaning of God in the Bible will have a liberating and humanizing power if the meaning of God is not applied directly but in dialogue with the actual beliefs of the community where the Bible is read and preached. The hermeneutic perspective of fusion horizon like this presupposes that the texts of the scriptures as well as the formulations of dogmas and actual beliefs of the community in culture need to undergo a double process, namely reproduction-traditional and productive-contextual. ${ }^{55}$ This means that traditional heritages (the Bible, dogmas and actual beliefs) need to be reproduced by taking into account the new dynamics of the context, so that these heritages give value and meaning to the new experiences of today's people. The legacy of the past is not finished materials but raw materials. As a raw material it is not appropriate if it is directly applied. Need to apply creatively. ${ }^{56}$ The creative application departs from new meanings obtained from a reciprocal, constructive and dialectical dialogue between the Bible and dogma (the universal tradition) and the actual beliefs of the community (local traditions).

53 Titaley. Religiositas di Aline Tiga. 59.

54 A.A. Yewangoe. Agama dan Kerukunan. (Jakarta: BPK Gunung Mulia, 2006), 49.

55 Nuban Timo. "Sosiologi Agama dalam Perspektif Teologi Dogmatik", 50. 2009), 38.

56 Deborah Beth Creamer. Disability and Christian Theology. (New York: Oxford University Press. 


\section{CONCLUSION}

Hermeneutics as above is applied in theological tasks, of course there will be many versions of God and His meaning. Traditional heritage (the Bible, dogmas, and actual beliefs) needs to be reproduced by considering the dynamics of the new context, so that the heritage gives value and meaning to the new experiences of today's society. Creative applications depart from new meanings obtained from mutual, constructive and dialectical dialogue between the Bible and dogmas (universal traditions) and actual beliefs of society (local traditions).

\section{REFERENCE}

Andel, Henk van. De bijbel opnieuw... gelezen, uitgelegd, overwogen. 's-Gravenhage: Meinema, 1990.

Adiprasetya, Joas. Teologi Konstruktif dan Wajah Sosiologi Agama. in Izak Lattu, Rama Tulus Pilakoanmu, Ebenhaizer I Nuban Timo, Steven Gaspersz (Ed.). Sosiologi Agama Pilihan Berteologi di Indonesia. Salatiga: Fakultas Teologi Universitas Kristen Satya Wacana Press, 2016.

Bakker, J.T. "Het gezag van het schrift." Dalam Rondom het Woord. Theologische Etherleergang van de NCRV. No. 3 (Juli. 1968).

Barth, Karl. Church Dogmatics, The Doctrine of the Word of God 1.2. New York: T\&T Clark, 2010.

Bevans, Stephen. "Models of Contextual Theology." Missiology, Vol.13, No.2 (April 1985): 185-202. https://doi.org/10.1177/009182968501300205.

Bevans, Stephen B. Teologi Dalam Perspektif Global. Sebuah Pengantar. Maumere: Penerbit Ledalero, 2010.

Cairns, I. Perjanjian Lama dan Indonesia Yang Sedang Membangun. Jakarta: BPK Gunung Mulia, 1985.

Creamer, Deborah Beth. Disability and Christian Theology. New York: Oxford University Press. 2009.

Deere, Jack. Surprised by the Power of the Spirit. Grand Rapids, Michigan: Zondervan Publishing, 2020. 
Hughes, Philip. "The Use of Actual Beliefs in Contextualizing Theology." East Asia Journal of Theology. Vol.2, No.2 (1984).

Kantor Pusat HKBP. Panindangion Haporseaon. Pengakuan Iman HKBP. Pematang Siantar: Unit Usaha Percetakan HKBP, 2009.

Kapic, Kelly M. Pedoman Ringkas Berteologi, Mengapa dan Bagaimana Study Teologi. Diterjemahkan oleh Paul S. Hidayat. Jakarta: Waskita Publishing. 2014.

Ord, David Robert \& Coote, Robert B. Apakah Alkitab Benar? Memahami Kebenaran Alkitab Pada Masa Kini. Jakarta: BPK Gunung Mulia, 2016.

Ng'ang'a, Abraham Waigi. "Why Contextual Theology Matters for the Church." InSights Journal for Global Theological Education, Vol.3, No.1 (2017): 25-32.

Poerwowidagdo, Judo. Mengkomunikasikan Injil Melalui Lambang-Lambang dan Citra-citra Indonesia: Dahulu dan Sekarang. in Persetia: Berteologi Dengan Lambang-Lambang dan Citra-Citra Rakyat. Jakarta: Persetia, 1992.

Ruku, Welfrid Fini. Fenomena Kutuk/Berkat di Rumah Naomi. Hermeneutik Etnofenomenologi Atoin Meto di Timor Atas Kitab Rut 1:1-6. Dissertation. Yogyakarta: Program Pasca-Sarjana S3 Ilmu Teologi Universitas Kristen Duta Wacana Yogyakarta, 2017.

Ruler, A.A. Van. "Schriftgezag en kerk ." in Rondom het Woord. Theologische Etherleergang van de NCRV. No. 3 (July 1968).

Timo, Ebenhaier I. Nuban. "Sosiologi Agama dalam Perspektif Teologi Dogmatika." in Izak Lattu, Rama Tulus Pilakoanmu, Ebenhaizer I Nuban Timo, Steven Gaspersz (Ed.). Sosiologi Agama Pilihan Berteologi di Indonesia. Salatiga: Fakultas Teologi Universitas Kristen, Satya Wacana Press, 2016.

Timo, Ebenhizer I. Nuban. Meng-hari-ini-kan Injil di Bumi Pancasila. Jakarta: BPK Gunung Mulia, 2017.

Timo, Ebenhizer I. Nuban. Pemberita Firman Pencinta Budaya. Mendengar dan Melihat Karya Allah dalam Tradisi. Jakarta: BPK Gunung Mulia, 2006.

Timo, Ebenhaizer I Nuban. Polifonik bukan Monofonik. Salatiga: Satya Wacana University Press, 2015.

Timo, Ebenhizer I. Nuban. Sidik Jari Allah di dalam Budaya. Maumere: Penerbit Ledalero, 2010. 
Shenk, David W. Ilah-Ilah Global. Menggali Peran Agama-Agama dalam Masyarakat Modern. Jakarta: BPK Gunung Mulia, 2006.

Titaley, John A. Religiositas di Aline Tiga. Pluralisme, Nasionalisme dan Transformasi AgamaAgama. (Salatiga: Satya Wacana University Press, 2013.

Verkuyl, J. Met Moslims in Gesprek Over het Evangelie. Kampen: J.H. Kok, 1994.

Yewangoe, A.A. Agama dan Kerukunan. Jakarta: BPK Gunung Mulia, 2006. 